\title{
Spinal Extradural Arachnoid cyst: Review of Literature
}

Siddharth Verma *, Reena Soni,

Department of Neurosurgery, Mittal hospital \& research center, Ajmer (Rajasthan), India.

*Corresponding author: Siddharth Verma, Department of Neurosurgery, Mittal hospital \& research center, Ajmer (Rajasthan), India.

E-mail: drsverma1983@gmail.com

Received Date: February 05, 2020; Accepted Date: February 14, 2020; Published Date: February 18, 2020.

Citation: Verma S, Soni R. (2020) Spinal Extradural Arachnoid Cyst: Review of Literature. Journal of Surgical Case Reports and Images, 3(2): Doi: $10.31579 / 2690-1897 / 020$

Copyright: (C) 2020. Siddharth Verma. This is an open-access article distributed under the terms of the Creative Commons Attribution License, which permits unrestricted use, distribution, and reproduction in any medium, provided the original author and source are credited.

\section{Introduction}

Spinal arachnoid cysts are mostly intradural. Spinal extradural arachnoid cyst (SEAC) is very rare condition accounting for only $1 \%$ cases of spinal tumors. [1,2,3] SEAC is mostly found in males in their second to fifth decades. ${ }^{3}$ Most common location of SEAC is thoracic spine [1,2,3].

SEAC results from tiny Dural defect through which outpouching herniation of arachnoid membrane takes place $[1,2]$. Etiology of SEAC
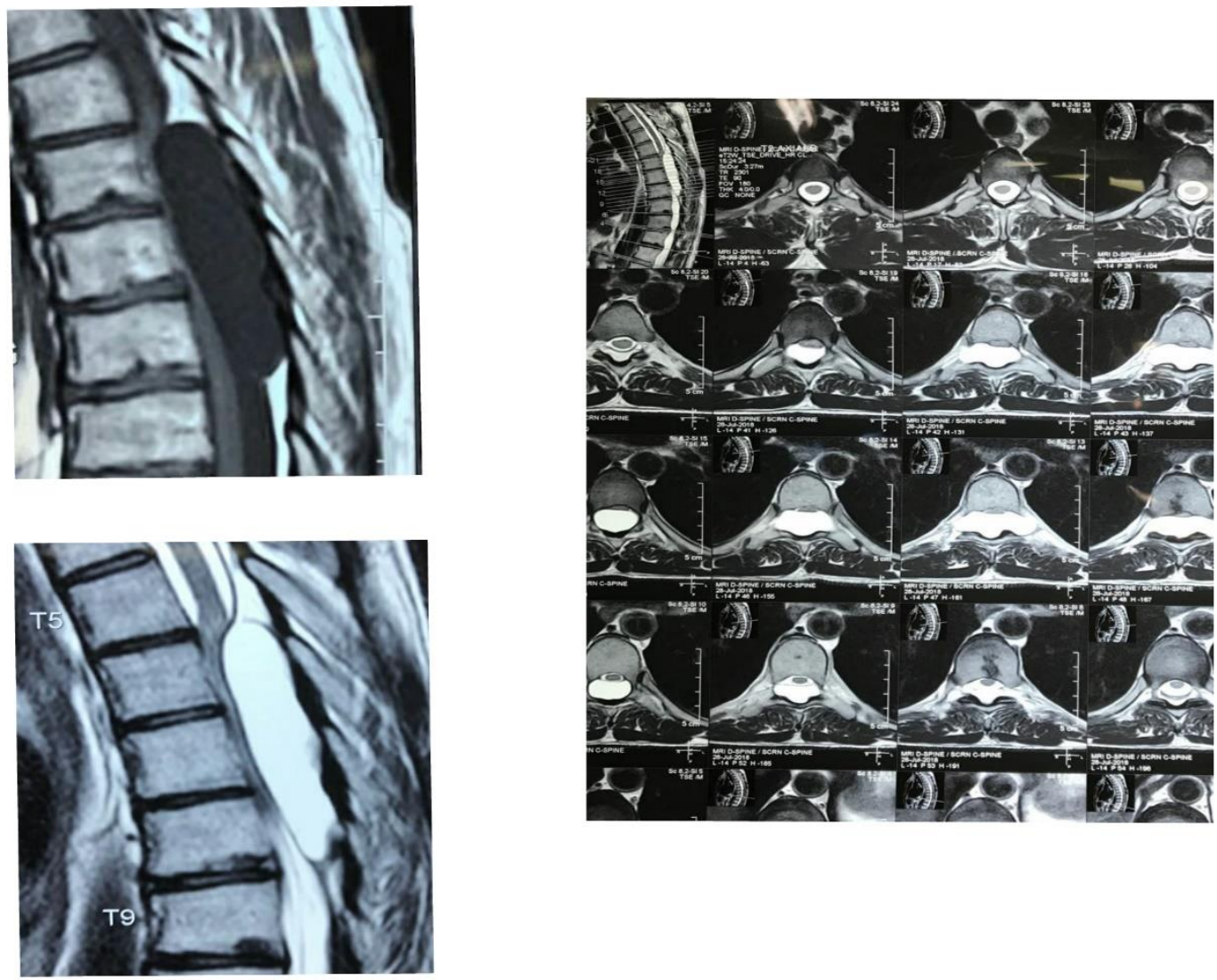

(MRI showing arachnoid cyst extending from D5 to D8.) still remains unclear but can be congenital, post traumatic and post infective $[1,2,4]$. SEAC may enlarge with time and can exert mass effect over cord and/or root and produce myelopathy and radiculopathy $[1,2$, and 5]. These cysts enlarge during exercise or Valsalva maneuvers as these cysts communicates with subarachnoid space [1, 6]. Small, asymptomatic cysts can be observed but symptomatic cysts require surgery. Various surgical techniques have been described but still there is no consensus [1,2, and 7]. 


\section{Review of Literature}

SEAC is a rare cause of compressive myelopathy, which accounts for only $1 \%$ of all spinal tumors [1, 2, and 3]. It is more common in males in their 20s [3]. Thoracic spine is most common location [1, 2, and 3].

SEAC results from herniation of arachnoid membrane through the tiny dural defect $[1,2]$. These cysts communicate with subarachnoid space through which CSF accumulates [1, 6]. Rarely, the cyst does not have any communication with subarachnoid space ${ }^{12}$. Etiology of these dural defects still remains unclear. These defects can be congenital or acquired $[1,2,4]$. Acquired causes can be trauma, infection or inflammation [1, 2, 4]. It may be associated with dural ectasia, Marfan syndrome [1]. In this condition, organization of collagen is defective, which results in decreased tensile strength of ligamentous structures and other supporting tissues [8]. Dural stretching can lead to dural thinning to such an extent that it becomes ectatic and may be deficient in areas [8]. Although there is still debate in determining the etiology of SEACs, the theory of congenital dural defect is widely accepted [8]. Dural defect is often present near the nerve root sleeves. Proposed reason is that tension across the movable dural sac and relatively fixed roots can predispose such dural defects $^{2}$. Outpouching of arachnoid takes place through these small defects $[1,2]$. These herniations become enlarge with time during exercise or Valsalva [1,6]. It explains the symptomatic fluctuation during exercise and Valsalva maneuvers. Based on this, pulsatile CSF flow dynamic theory was proposed by many authors to explain enlargement of cyst $[1$, $2,9]$. These defects may act like valve as defects are small and arachnoid herniates beyond their margins. Rootlets may also get trapped and it again act like a valve ${ }^{2}$. As enlargement continues, a SEAC can aggravate spinal cord compression or nerve root compression, which leads to myelopathy or radiculopathy $[2,3,4]$. Nabors et al. classified in to 3 categories [10].

1. Type 1: Extradural cyst without nerve tissue. 1A-Extradural meningeal cyst, 1B- Sacral meningocele.

2. Type 2: Extradural cyst containing nerve tissue.

3. Type 3: Spinal cyst.

MRI is the most useful tool to diagnose a SEAC [3] Radiological studies report that a SEAC appears similar to cerebrospinal fluid [2, 3, 7] A CT myelography is also a useful diagnostic tool as it can more reliably detect the anatomical location of the cyst [2] In addition, a myelogram and CT myelography can help locate the Dural defective site [2, 4]. CSF flow MRI can identify the pulsating turbulent flow void of a defective site [1].

Symptomatic cyst needs surgical treatment [1, 2, and 7]. There is a consensus among surgeons to repair the dural defect in the treatment of a SEAC. However, there is still disagreement regarding the treatment of the cyst [2,3,4]. Diverse surgical techniques have been described and complete microsurgical resection of SEACs with meticulous repair of dural defect has been advocated as treatment of choice for SEACs [2, 9]. Long segment laminectomy and complete excision of cyst may be associated with complications like bleeding, post-operative kyphotic deformity and instability $[1,3,4,7,8]$. Alternative surgical techniques have been described to avoid these complications. Payer et al described selective interlaminar fenestration at communication site with repair of dural tear. Communication site was identified as flow void seen on preoperative cine MRI [9]This technique has an advantage of minimal laminotomy but requires very precise localization of Dural defect that may not be possible every time. Woo et al described laminectomy at defect site, penetration of cyst and Dural repair [11]. But they had to extent their laminectomy because of spatial limitation or not finding dural defect. Won Choi et al described tailored laminectomy, fenestration and closure of dural defect [1]. Javier Quillo-Olvera et al did evacuatory puncture of cyst and concluded that if the patient has mild symptoms, clinical observation is recommended [13].

\section{Conclusion}

SEACs are rare cause of compressive myelopathy but should be kept in mind as they respond very well after surgery. Various surgical techniques have been described. Meticulous repair of dural defect is necessary to prevent recurrence.

- The authors have no financial conflicts of interest.

\section{References:}

1. Lee CH, Hyun SJ, Kim KJ, Jahng TA, Kim HJ. (2012). what is a reasonable surgical procedure for spinal extradural arachnoid cysts: is cyst removal mandatory? Eight consecutive cases and a review of the literature. Acta Neurochir (Wien) 154:12191227.

2. Choi SW, Seong HY, Roh SW. (2013). Spinal extradural arachnoid cyst. J Korean Neurosurg Soc 54:355-358.

3. Netra R, Min L, Shao Hui M, Wang JC, Bin Y, Ming Z. (2011). Spinal extradural meningeal cysts: an MRI evaluation of a case series and literature review. J Spinal Disord Tech 24:132-136.

4. Panigrahi S, Mishra SS, Dhir MK, Parida DK. (2012). Giant thoracolumbar extradural arachnoid cyst: an uncommon cause of spine compression. Neurol India 60:540-542.

5. Furtado SV, Thakar S, Murthy GK, Dadlani R, Hegde AS. (2011). Management of complex giant spinal arachnoid cysts presenting with myelopathy. J Neurosurg Spine 15:107-112,

6. Doita M, Nishida K, Miura J, Takada T, Kurosaka M, Fujii M . (2003). Kinematic magnetic resonance imaging of a thoracic spinal extradural arachnoid cyst: an alternative suggestion for exacerbation of symptoms during straining. Spine (Phila Pa 1976) 28: E229-E233.

7. Funao H, Nakamura M, Hosogane N, Watanabe K, Tsuji T, Ishii K, et al. (2012). Surgical treatment of spinal extradural arachnoid cysts in the thoracolumbar spine. Neurosurgery 71:278-284,

8. Oh JK, Lee DY, Kim TY, Yi S, Ha Y, Kim KN, et al. (2012). Thoracolumbar extradural arachnoid cysts: a study of 14 consecutive cases. Acta Neurochir (Wien) 154: 341-348; discussion 348.

9. Payer M, Brühlhart K. (2011). Spinal extradural arachnoid cyst: review of surgical techniques. J Clin Neurosci 18: 559-560,

10. Nabors MW, Pait TG, Byrd EB, Karim NO, Davis DO, Kobrine AI, et al. (1988). Updated assessment and current classification of spinal meningeal cysts. J Neurosurg 68: 366-377.

11. Joon Bum Woo, Dong Wuk Son, Kyung Taek Kang, Jun Seok Lee, Geun Seong Song, (2016). Spinal Extradural Arachnoid Cyst. Korean J Neurotrauma.12(2):185-190

12. Kim IS, Hong JT, Son BC, Lee SW. (2010). Noncommunicating spinal extradural meningeal cyst in thoracolumbar spine. J Korean Neurosurg Soc 48: 534-537. 
13. Javier Quillo-Olvera, Javier Quillo-Resendiz, Carlos-Francisco Gutierrez-Partida, Manuel Rodriguez-Garcia. (2017). Spinal extradural arachnoid cyst: A casr report and review of literature. Cirugia y Cirujanos 85(6):544-548.

\footnotetext{
Ready to submit your research? Choose Auctores and benefit from:

* fast, convenient online submission

* rigorous peer review by experienced research in your field

* rapid publication on acceptance

* authors retain copyrights

* unique DOI for all articles

* immediate, unrestricted online access
}

At Auctores, research is always in progress.

Learn more www.auctoresonline.org/journals/journal-of-surgical-casereports-and-images 